\title{
PENGATURAN DAN IMPLIKASI PENGUJIAN FORMIL UNDANG-UNDANG DI MAHKAMAH KONSTITUSI
}

\author{
Fathorrahman \\ Program Studi Hukum Fakultas Ilmu Sosial dan Humaniora \\ Universitas Ibrahimy Situbondo \\ Email : aryawiraraja.45@gmail.com
}

\begin{abstract}
Abstraks
Sebagai lembaga yang memiliki fungsi khusus, Mahkamah Konstitusi memiliki kewenangan kehakiman yang berbeda dengan lembaga kehakiman lainnya. Ia memiliki atribusi khusus dan terbatas dalam menjalakan kewenangan dan fungsinya dalam sistem ketatanegaraan di Indonesia. Salah satu kewenagan yang dimiliki oleh Mahkamah Konstitusi adalah menguji validitas produk lembaga legislatif berupa Undang-Undang yang potensial bertengtangan dengan UndangUndang Dasar Negara Republik Indonesia. Secara umum, semua produk legislasi harus memenuhi tertib norma dan tertib prosedur. Tertib norma yang dimaksud adalah isi dari Undang-Undang tidak bertentangan dengan UUD NRI. Sedangkan untuk tertib prosedural adalah alpanya pelanggaran dalam membentuk UndangUndang dari hulu hingga akhir. Tertib keduanya disebut sebagai tertib materil dalam aspek norma, dan tertib formil dalam aspek prosedur. Dalam kajian ini, ada beberapa hal yang hendak dilacak : Apakah terdapat pengaturan secara eksplisit tentang pengujian formil di Mahkamah Konstitusi dan apa implikasi hukum terkait putusan Mahkamah Konstitusi atas pengujian formil sebuah Undang-Undang. Kedua rumusan masalah di atas akan dilakukan analisis dengan menggunakan pendekatan konseptual-teoritik dan yuridis-normatif, serta pendakatan kasus terkait putusan yang pernah ada.
\end{abstract}

Kata Kunci : Pengujian formil, Mahkamah Konstitusi dan Peraturan perundangundangan

\begin{abstract}
As an institution that has a special function, the Constitutional Court has judicial authority that is different from other judicial institutions. It has a special and limited attribution in carrying out its authority and function in the constitutional system in Indonesia. One of the powers possessed by the Constitutional Court is to examine the validity of legislative products in the form of laws that have the potential to conflict with the Constitution of the Republic of Indonesia. In general, all legislation products must comply with orderly norms and procedures. Orderly norms in question is the
\end{abstract}


content of the Act does not conflict with the Constitution of the Republic of Indonesia. As for procedural order, it is the absence of violations in forming laws from upstream to final. The order of the two is referred to as material order in the aspect of norms, and formal order in the aspect of procedure. In this study, there are several things to be tracked: Is there an explicit regulation on formal examination in the Constitutional Court and what are the legal implications regarding the decision of the Constitutional Court on the formal review of a law. The two problem formulations above will be analyzed using conceptual-theoretical and juridicalnormative approaches, as well as case approaches related to existing decisions.

Keywords : Formal review, Constitutional Court and Legislation

\section{PENDAHULUAN}

\section{A. Latar Belakang}

Pengujian sebuah peraturan perundang-undangan di Indonesia, kewenangannya terdiaspora ke berbagai lembaga. Terdapat banyak lemaga yang menyelenggarakan fungsi tersebut. Salah satu bentuk pengujian peraturan perundang-undangan adalah pengujian terhadap undang-undang. Pengujian terhadap jenis undang-undang dikenal dua model atau istilah dalam beberapa teori dan konsepsi. Seperti yang tertulis dalam bukunya Jimly Asshiddiqie bahwa pengujian undang-undang oleh mahkamah dibedakan antara judicial review dan yudicial preview ${ }^{1}$. Model yudicial preview adalah melihat sebuah undang-undang sebelum dilakukan penetapan oleh lembaga otoritatif. Artinya, peninjauan pada model ini dilakukan sebelum terhadap rancangan seutu peraturan perundangundangan ${ }^{2}$. Berbeda dengan yudicial preview, cara melihat atau meninjau dengan instrumen yudicial review lebih mengedepankan proses peninjauan pada tahap di mana sebuah undang-undang sedah ditetapkan diundangkan dalam lebaran negara ${ }^{3}$.

Jika ditelusuri dalam beberapa naskah, terdapatnya insrtumen peninjauan kembali terhadap sebuah bentuk peraturan perundang-undangan adalah demi terjaminnya sebuah check and balance dalam penyelenggaraan fungsi-fungsi negara oleh lembaga pemerintahan. Secara umum, sebuah kewenangan tanpa

\footnotetext{
${ }^{1}$ Jimly Asshiddiqie, Hukum Acara Pengujian Undang-Undang (Jakarta: Konstitusi Press, 2006).

${ }^{2}$ Ibid.

${ }^{3}$ Ibid.
} 
adanya alat kontrol oleh lembaga lain akan menimbulkan kesewenang-wenangan dalam menjalankan fungsi.

Hal tersebut tergambar dalam berkas yang di Mahkamah Konstitusi yang menyebutkan bahwa kewenangan dalam menjalakan fungsi dalam melakukan peninjauan kembali terhadap undang-undang, semata untuk menjalakn fungsi check and balance agar terhindar kesewenang-wenangan oleh lembaga pemerintahan ${ }^{4}$. Dus, berbagai instrumen peninjauan kembali yang ada diharapkan mampu menghadirkan prinsip yang kuat bagi pembentuk undang-undang agar menerapkan asas kehati-hatian saat membahas sebuah rancangan undangundang5.

Sebagai upaya untuk memastikan terselenggaranya tata kelola negara dan pemerintahan yang baik, dibentuklah Mahkamah Konstitusi dengan fungsi khusus dalam ketatanegaraan di Indonesia. Gagasan dibentuknya Mahkamah Konstitusi merupakan ikhtiar dalam rangka menegakkan prinsip-prinsip negara hukum ${ }^{6}$. Selain itu, fungsi dari Mahkamah Konstitusi adalah menjamin perlindungan yang maksimal terhadap demokrasi dan hak-hak warga negara ${ }^{7}$. Beberapa alasan lain terkait motif dibentukknya Mahkamah Konstitusi adalah menghindari pengalaman buruk di masa lalu terhadap terdapatnya multi tafsir atau banyaknya tafsir ganda atas konstitusi ${ }^{8}$. Dengan begitu, hak tafsir yang otoritatif atas konstitusi pasca terbentuknya Mahkamah Konstitusi menjadi kewenangan tunggal dan tafsir tunggal oleh Mahkamah Konstitusi.

Artinya, salah satu kewenangan utama Mahkamah Konstitusi adalah dalam sistem ketatanegaraan kita adalah menguji undang-undang terhadap UndangUndang Dasar Negara Republik Indonesia. Pengujian konstitusionalias tersebut terlihat pada Pasal 24C ayat (1) Undang-Undang Dasar Negara Republik Indonesia (UUD NRI) yang memberikan wewenang kepada Mahkamah Konstitusi untuk

\footnotetext{
4 Tim Penyusun, Hukum Acara MK (Sekretariat Jenderal dan Kepaniteraan, Mahkamah Konsititusi, Jakarta, 2010).

5 Saldi Isra, "Peran Mahkamah Konstitusi dalam Penguatan Hak Asasi Manusia Di Indonesia” (2014) Vol.

11 Jurnal Konstitusi.

${ }^{6}$ I Dewa G Palguana, “Constitutional Question : Latar Belakang dan Praktik Di Negara Lain Serta

Kemungkinan Penerapannya Di Indonesia” (2010) Vol. I Ius Quia Iustum.

7 Ibid.

${ }^{8}$ Imam Soebechi, Hak Uji Materiil, cet. 1 (Jakarta: Sinar Grafika, 2016).
} 
menguji undang-undang terhadap UUD NRI.

Dalam sisi teori dan praktik, terdapat dua sistem pengujian konstitusionalitas undang-undang terhadap UUD NRI yakni pengujian secara formil ataupun materiil ${ }^{9}$. Dalam teori pengujian (toetsing), terdapat perbedaan antara pengujian materiil (materiil toetsing) dan pengujian formil (formelee toetsing ${ }^{10}$. Dalam pengujian materiil, objek pengujian lebih menekankan pada aspek materi muatan undang-undang. Apakah terdapat konten dalam undangundang yang secara materi bertengtangan dengan norma yang terdapat dalam konstitusi. Artinya, jika pengujian tersebut terkait materi muatan undang-undang, maka hal tersebut disebut dengan pengujian materiil. Sedangkan dalam pengujian formil adalah objek pengujiannya terkait prosedur pembentukan undang-undang sebagai suatu prudok hukum ${ }^{11}$.

Pengujian dari sisi formil adalah motede untuk melihat dan meninjau sejauh mana ketaatan para pembentuk undang-undang dalam melakukan proses pembentukan perundang-undangan. Apakah terdapat tertib prosedur yang dihilangkan dan terdapat beberapa tahapan yang tidak dilalui sesui dengan peraturan perundang-udangan.

Praktiknya, tidak pernah ada putusan mahkamah yang mengabulkan permohonan terkait pengujian dari aspek formil. Walaupun, terdapat beberapa permohonan yang masuk dan disidangkan oleh mahmakah konstitusi. Oleh sebab itu, pada artikel ini akan dilakukan kajian mendalam terhadap peninjauan dalam aspek formil.

\section{B. Rumusan Masalah}

Artikel ini mengkaji dua hal. Pertama, apakah terdapat dasar hukum yang kuat yang dapat dijadikan panca hukum utama dalam melakukan pengujian undang-undang pada aspek formil. Dan kedua, implikasi hukum apa yang akan ditimbulkan jika permohonan pengujian aspek formil dikabulkan hakim mahkamah.

\footnotetext{
${ }^{9}$ Asshiddiqie, supra note 1.

10 Ibid.

${ }^{11}$ Ibid.
}

\section{HUKMY|Jurnal Hukum}




\section{Motode Penelitian}

Adapaun penelitian ini menggunakan metode motode penelitian yuridis normatif dengan pendekatan konsep-teoritik ditamab dengan pendekatan kasus yang terdapat dalam siklus permohonan yang ada di Mahkamah Konstitusi.

\section{PEMBAHASAN}

Max Boli Sabon secara ekstrim mengatakan bahwa : tanpa konstitusi, negara tidak mungkin ada ${ }^{12}$. Hal tersebut dilatarbelakangi bahwa tidak terdapat satupun negara modern di dunia ini yang tidak memiliki sebuah peraturan fundamental atau yang secara awam disebut sebagai konstitusi. Sebab, konstitusi merupakan aturan dasar yang menjadi validitas terhadap sah tidaknya peraturan perundang-undangan lainnya. Oleh sebab itu, salah satu cara yang dapat diikhtiarkan untuk sekuritas agar seluruh produk dari peraturan perundang-undangan (undang-undang) memiliki konstitusionalitas, maka dibentuklah Mahkamah Konstitusi.

Dalam konteks ketatanegaraan Indonesia, konstitusi atau aturan dasar tersebut tergambar dalam bentuk nama Undang-Undang Dasar Negara Republik Indonesia. Undang-Undang Dasar NRI 1945 adalah sekumpulan ketentuan fundamental atau perihal yang punca (dasar ) yang terdapat dalam suatu kodifikasi mengenai hal-hal yang disebutkan di atas pada konteks menjalakan sistem ketatanegaraan suatu negara ${ }^{13}$. Sebagai hukum tertinggi, ia memiliki implikasi terhadap struktur dan mekanisme penyelenggaraan pemerintahan ${ }^{14}$. Termasuk juga mempunyai implikasi terhadap peraturan perundangan lainnya.

Untuk menjamin sekuritas terhadap penyimpangan akan konstitusi, MK dibentuk dan diberikan kewenagan untuk dapat melakukan pengujian undang-undang yang potensial bertengtangan dengan UUD NRI. Pembentukan MK terlihat dari amandemen UUD NRI yang di dalamnya terdapat pasal penyebutan MK pada pasal 24C. Jika melihat beberapa ayat yang terdapat pada pasal tersebut, maka MK diberikan dua tugas utama.

Pertama, ia diberi kewenangan untuk menyelenggarakan pengujian sebuah

\footnotetext{
12 Max Boli Sabon, Fungsi Ganda Konstitusi (Bandung: PT Grafiti, 1991).

13 Joeniarto, Undang-Undang Dasar 1945 Sebagai Hukum Negara yang Tertinggi (Jakarta: PT Bina Aksara, 1982).

14 Soimin \& Mashuriyanto, Mahkamah Konstitusi Dalam Sistem Ketatanegaraan Indonesia (Yogyakarta: UII Press, 2013).
} 
undang-undang yang berpotensi melanggar UUD NRI 1945, memberikan putusan atas sengketa lembaga negara dengan atribusi yang diberikan oleh Undang-Undang Dasar, memberikan penetapan atatu putusan terkait pembubaran suatu partai politik dan memberikan putusan vonnis atas perselisihan yang muncul tentang hasil pemilihan umum yang telah diselenggarakan, yang semua kewenangan tersebut final dan mengikat. Kedua, ia diberi satu kewajiban untuk memberikan sebuah putusan atas kemumgkinan munculnya pendapat Dewan Perwakilan Rakyat mengenai potensi pelanggaran atau dugaan pelanggaran yang dilakukan oleh presiden dan/atau wakil presiden.

Sebagai bentuk komitmen terhadap pembentukan MK, disahkanlah UndangUndang Nomor 24 Tahun 2003 tentang Mahkamah Konstitusi. Setelah terbitkan undnag-undang MK, maka kewenangan judicial review yang sebelumnya dilaksanakan oleh Mahkamah Agung karena MK belum terbentuk, maka beralih secara otomatis ke MK sebagi lembaha kehakiman yang independen. Apalagi salah satu kewenangan urgen yang dimiliki adalah kewenangan untuk menguji produk hukum yang dibentuk oleh lembaga legislatif.

Penjelasan umum yang terdapat dalam Undang-Undang Nomor 24 Tahun 2003 tentang Mahkamah Konstitusi (UU MK) adalah MK diberikan kompetensi untuk menyelesaikan perkara-perkara yang muncul dalam sistem ketatanegaraan Indonesia. Kompetensi tersebut dimaksudkan agar persoalan konstitusionalitas tertentu dapat teratasi dengan baik. Artinya, kompetensi yang diberikan kepada MK sebagai wujud dari menjaga konstitusi agar diselenggarakan secara bertanggungjawab sesuai dengan kehendak publik dan cita-baik demokrasi itu sendiri. Dari penjelasan tersebut dapat kita bahwa terdapat beberapa unsur yang terkandaung di dalamnya. Fungsi tersebut dikonfigurasikan dalam bentuk kewenangan yang diberikan kepada MK. Unsur dalam penjelasan yang ada dapat kita rinci bahwa fungsi MK berupa : a). Penafsir final konstitusi; b). Pengawal konstitusi; c.) Pelindung hak konstitusional warga negara; d). Pelindung hak asasi manusia dan e). Pelindung demokrasi.

Selain itu, wewenang MK yang tertulis dalam UUD NRI dan dipertegas kembali dalam UU MK bahwa : "mengadili pada tingkat pertama dan terakhir yang bersifat final untuk menguji undang-undang terhadap UUD NRI; memutus sengketa wewenang lembaga negara yang wewenangnya diberikan oleh UUD NRI; memutus pembubaran 
partai politik; dan memutus perselisihan tentang hasil pemilu". Terkait dengan wewenang untuk mengadili pada tingkat pertama dan terakhir yang bersifat final untuk menguji undang-undang terhadap UUD NRI merupakan wewenang utama dan pada praktiknya pun menjadi wewenang yang mendominasi gelaran perkara ${ }^{15}$.

Selain diberikan wewenang, MK juga berkedudukan untuk menilai pendapat DPR RI atas dugaan pelanggaran yang dilakukan oleh Presiden dan/atau Wakil Presiden. Kedudukan yang diberikan secara normatif tersebut bersifat wajib.

Dalam melakukan pengujian, hak menguji terbagi menjadi dua bentuk yakni menguji secara formal (formele toetsubfrecht), menguji keabsahan prsedur pembentukan ${ }^{16}$. Dan keuda, menguji materil (materiele toetsubfrecht), melihat materi kesesuaian materi undag-undang terhadap norma yang lebih tinggi17. Dalam perubahan UU MK yang kedua (Undang-Undang Nomor 8 Tahun 2011), terdapat penegasan yang cukup eksplesit terkait kewenangan MK atas pengujian undangundang terhadap UUD NRI. Awalnya, materi muatan pada undang-undang sebelumnya, mengatur kewenangan MK lebih dominan hanya pada pengujian pas aspek matiril. Hal itu tergambar pada Pasal 60 yang tertulis bahwa terhadap materi muatan ayat, pasal, dan/bagian dalam undang-undang yang telah diuji, tidak dapat dimohonkan kembali18.

Perubahan tersebut dapat dibaca bahwa pengujian undang-undang terhadap UUD NRI yang semula tidak secara rinci dan tegas menyebutkan norma terhadap pengujian formil. Pada perubahan kedua, terdapat penegasan dan penambahan baru yakni pengujian pada aspek formil lebih diperkuat. Walaupun, pengujian formil, sebenarnya sudah ada pada Pasal 51 ayat (3) pada UU MK 24/2003. Tetapi, jika dilacak lebih detail, tidak terdapat pengaturan secara lengkap terkait pengujian formil. Penegasan pengujian formil dapat dilihat pada pasal 51A ayat (3) dan (4). Pada ayat (3) yang norma berbunyi bahwa : "dalam hal permohonan pengujian berupa permohonan pengujian formil, pemeriksaan dan putusan yang dilakukan oleh MK didasarkan pada peratuarn perundang-perudangan yang mengatur tata cara

\footnotetext{
${ }^{15}$ Murarar Siahan, Hukum Acara Mahkamah Konstitusi Republik Indonesia (Jakarta: Sinar Grafika, 2012). ${ }^{16}$ Idul Rishan, "Konsep Pengujian Formil Undang- Undang di Mahkamah Konstitusi" (2021) 18 Jurnal Konstitusi.

17 Mohammad Mahrus Ali, “Konstitusionalitas dan Legalitas Norma dalam Pengujian Undang-Undang Terhadap Undang-Undang Dasar 1945” (2015) 12 Jurnal Konstitusi.

18 Undang-Undang Nomor 24 Tahun 2003 tentang Mahkamah Konstitusi (Lembaran Negara Republik Indonesia Tahun 2003 Nomor 98).
} 
pembentukan peraturan perundang-undangan" 19 .

Secara konsep, pengujian materil adalah pengujian terhadap materi muatan undang-undang yang dianngap bertengtangan dengan UUD NRI. Implikasi dari dari pengujian materil batalnya sebagian atau seluruhnya yang bersangkutan ${ }^{20}$. Terhadap hak uji materil, Sri Soemantri, membuat batasan terhadap pengujian materil adalah suatu wewenang untuk menyelidiki dan kemudian menilai, apakah suatu peraturan perundang-undangan isinya sesuai atau bertentangan dengan peraturan yang lebih tinggi derajatnya, serta apakah suatu kekuasaan tertentu (verordenende macht) berkah mengeluarkan suatu peraturan tertentu ${ }^{21}$.

Sedangkan untuk pengujian formil tidak terkait dengan materi muatan, akan tetapi berkelindan dengan produk hukum atau proses pembentukan perudang-undangan ${ }^{22}$. Pengujian formil itu sendiri tidak identik dengan pengujain atas undang-undang, meskipun pengujian atas bentuk dapat juga disebut sebagai salah satu pengujian formil ${ }^{23}$.

Secara umum pengujian dari sisi formil terbilang sangat komplek. Tolok ukur yang dapat digunakan untuk menilai apakah suatu undang-undang kehilangan konstitusionalitas dari aspek formalnya, adalah sejauh mana undang-undang itu ditetapkan secara teapat dalam segi bentuk (appopriate form), tepat institusi yang menetapkannya (appopriate institution) dan tepat menurut prosedural yang berlaku dan baku (appopriate procedure) ${ }^{24}$.

Walaupun pengujian secara formil lebih komplek daripada pengujian pada aspek materil, akan tetapi pengujian model ini sangatlah jarang dimohonkan. Dari perkara yang tercatat, MK lebih banyak menyelenggarakan pengujian maateril undang-undang. Bahkan, jika melihat beberapa putusan MK atas perkara pengujain formil, tidak pernah ditemukan amar putusan yang mengabulkan permohon pada aspek formil.

Dari data yang ada, tidak terdapat putusan MK yang membatakan undang-

\footnotetext{
${ }^{19}$ Undang-Undang Republik Indonesia Nomor 8 Tahun 2011 Perubahan Atas Undang-Undang Nomor 24 Tahun 2003 Tentang Mahkmah Konstitusi (Lembaran Negara Republik Indonesia Tahun 2011 Nomor 70). ${ }^{20}$ Asshiddiqie, supra note 1.

${ }^{21}$ Sri Soemantri, Hak Menguji Material di Indonesia (Bandung: Penerbit Alumni, 1986).

${ }^{22}$ Asshiddiqie, supra note 1.

23 Ibid.

24 Ibid.
}

140 HUKMY |Jurnal Hukum 
undang karena dianggap cacat prosedur. Bakan, putusan MK Nomor 27/PUU-VII/2009 terhadap perkara uji formil atas Undang-undang Nomor 3 Tahun 2009 tentang Mahkamah Agung memberikan putusan bahwa terdapat cacat prosedul, namun demi kemanfatan, Undang-Undang tersebut dinyatakan tetap berlaku.

Jika dilihat dari bergbagai data yang ada, gagalnya pengujian formil di MK disbebakan beberapa faktor. Pertama, permohonan pada uji formil masih bergantung pada interpretasi hakim ${ }^{25}$. Jika diamati, terdapat pembelahan poradimatik yang sangat jauh berbeda. Hal itu tergambar dari beberapa putusan MK atas perkara yang tergelar. Kedua, secara tidak profesional, terdapat pola delegasi kewenangan dari pembentuk undang-undang kepada lemabaga penerima delegasi dalam pembentukan peraturan pelaksana dan ketiga, lemahnya kualitas pembuktian yang disajikan oleh pemohon ${ }^{26}$.

Dari beberapa faktor tersebut menunjukkan bahwa pengujian formil di siklus perkara di MK belum menjadi konsentrasi yang mendapat perhatian cukup. Padahal, keabsahan sebuah peraturan perundang-undangan juga dipengaruhi oleg aspek prosedural pemebntukan peratuarn perudang-undangan. Jika suatu peraturanperudangan cacat prosedur, harusnya ia tidak memiliki legitimasi sohih dan dalam hal ini MK perlu melihat sebagai bagian dari pengawal konstitusi.

Padahal, dalam menjalankan kewenangannya, MK sudah diberikan kewenangan untuk memberikan tafsir yang atribusi tersebut timbul dari sebuah tafsir : bahwa untuk menunjang supaya hakim bekerja dengan sangat baik dalam menggelar perkara konstitusinalitas maka ia diberikan kebebasan agar produk lembaga legislatif mempunyai kesesuaian dengan konstitusi ${ }^{27}$. Artinya, kewenangan menafsiri tersebut lahir dari sebuah penafsiran itu sendiri28. Kredo yang menyatakan bahwa Mahkamah Konstitusi disebut sebagai lembaga kekuasaan kehakiman "the guardian of constitution and the sole interpreting of constitution." Disebut sebagai penjaga terakhir konstitusi berdasarkan kompetensi yang dimiliki dalam memberikan putusan apakah sebuah produk perundang-undangan oleh lemabaga legislatif telah sesuai dengan konstitusi

\footnotetext{
25 Rishan, supra note 16.

26 Ibid.

27 Jimly Asshiddiqie, Setengah Abad Jimly Asshiddiqie, Konstitusi dan Semangat Kebangsaan (Jakarta: PT Sumber Agung, 2006).

28 Ibid.
} 
atau korelatif dengan konstitusi ${ }^{29}$.

Oleh sebab itu, MK diberi kewenangan untuk menafsiri apakah sebuah produk legislatif menyalahi proses yang sudah digariskan oleh peraturan perudang-undangan lainnya. Memang, jika MK menggunakan rujukan UUD NRI sebagai batu uji apakah terdapat ketidaksesuaian sebuah undang-undang terhadap UUD NRI, maka akan menemui kesulitan yang luar biasa. Hal itu dikarenakan dalam norma konstitusi kita tidak secara eksplesit menyebut batasan-batasan umum terkait kualitas atau syaratsyarat ketat prosedur pembentukan undang-undang.

Padahal, aspek prosedual dalam pembentukan undang-undang sering sekali diabaikan oleh para pembentuk undang-undang. Dari beberapa tertib yang sebenarnya diharapkan dalam membentuk peraturan perundang-undangan terdapat dua tertib. Pertama, sebuah peraturan perudang-undangan haruslah tertib norma; norma yang terdapat dalam undang-undang tersebut tidak bertengtangan dengan norma yang terdapat dalam konten peraturan yang secara hirarki berada di atasnya. Selain tertib norma, sebuah undang-undang juga harus mengikuti lintasan prosedural yang sudah ditetapkan. Artinya, ia harus mengikuti tertib formil sejak dari proses awal hingga pada tahap final, yakni pengundangan (due process of law making).

Dengan demikain, dalam konteks pengaturan pengujian undang-undang secara formil, sudah terdapat penormaan sejak awal MK dibentuk. Walaupun tidak tegas diatur dalam UUD NRI terkait batasan pengujian secara formil, akan tetapi MK juga diberikan ruang untuk menafsirkan norma yang terdapat dalam konstitusi karena ia berfungsi sebagai pengawal konstitusi. Batasan yang tidak secara tegas disebutkan dalam UUD NRI bukanlah alasan sohih untuk tidak mengabulkan permohonan pengujian undang-undang secara formil. Sifat supel dan luwes dalam beberapa norma yang terdapat dalam konstitusi itu dicitakan agar konstitusi kita mampu berkembang dan sanggup adaptif dengan alterasi sosial yang terjadi ${ }^{30}$.

Perhatian dan penguatan hakim MK dalam pengujian aspek formil ini harus menjadi konsentrasi. Konsentrasi yang memerlukan sebuah energi dan keberanian lebih mengingat terdapat beberpa faktor yang tidak bisa diindari dalam kehidupan

\footnotetext{
${ }^{29}$ Anonimous, “Eksistensi Lembaga Negara, Berdasarkan UU Negara RI Tahun 1945” (2007) Vol 4 Jurnal Legislasi.

${ }^{30}$ Christopher F Zurn, "Deliberative Democracy and the Institutions of Judicial Review" (2007) Cambridge University Press New York.
}

142 HUKMY | Jurnal Hukum 
bernegara kita saat ini. Kenyaataan di mana hungungan anatara lembaga legislatifa dan eksekutif sangatlah mesra. Konfigurasi bagi-bagi kue kekuasaan tergambar sangat jelas dari bentuk koalisi yang sangat kuat ${ }^{31}$. Kondisi ini dalpat menciptakan sebuah produk undang-undang yang tida sesuai dengan prosedur pembentukan yang diinginkan.

Dari konfigurasi politik tersebut, fungsi filter dan pengawasan lebih banyak dibebankan kepada hakim MK karena mereka tidak terlibat dalam persinggungan kekuasaan pemerintahan secara langsung. Meraka harus menjadi menjaga gawang yang melindungi kepentingan warga negara dari kemungkinan mendapat kerugian konstitusionalitas karena keaplaan para pembentuk undang-undang pada aspek formil pembentukan. Negara, dalam hal ini MK harus presentif dalam menyediakan fungsi menyamakan frekuensi antara prefensi warga negara dengan lembaga-lembaga pemerintahan untuk memeberikan pengawasan dan korektif pada setiap fase pembentukan peraturan perundang-undangan ${ }^{32}$.

Aspek prosedural bukanlah proses yang artifisial belaka. Ia memiliki sisi urgen yang menentukan konten dan implikasi dari keberlakuan peraturan perundangundangan tersebut. Taruhlah salaha satu syarat yang wajib terpenuhi dari aspek prosedural tersebut adalah keterlibatan masyrakat. Keterlibatan publik dalam rancangan peraturan-perundang-undangan adalah legitimasi utama apakah keberadaan undang-undang tersebut diinginkan dan sesuai dengan aspirasi masyarkat. Sebab, publik adalah penentu berbagai kebijakan, program dan rencana yang hendak diterbitkan oleh pemangku kebijakan. Rakyat pulalah yang menjadi enklave yang paling terdampak dari berbagai kebijakan yang ada. Maka, suara dan partisipasi publik tidak hanya menjadi instrumen prasyarat, tetapi itu ruh apakah undang-undang memiliki ruh yang sesuai dengan aspirasi dan kemauan publik.

Aspek yang tidak kalah urgen adalah kewajiban untuk melibatkan ahli dan akademisi dalam penyusunan naskah akademik. Naskah akademik menjadi dokumen yang penting agar peraturan yang akan ditetapkan memiliki kajian dan sudah melalui

\footnotetext{
${ }^{31}$ Kompas Cyber Media, "Menakar Kekuatan Politik Partai Koalisi Pemerintah di Tengah Menguatnya Wacana Amendemen UUD 1945... Halaman all", (1 September 2021), online: KOMPAS.com <https://nasional.kompas.com/read/2021/09/01/19461631/menakar-kekuatan-politik-partai-koalisipemerintah-di-tengah-menguatnya>.

32 Rishan, supra note 16.
} 
penelitian ilmiah. Sebuah kebijakan, termasuk semua bentuk dan jenis peraturan perundangan, harus memiliki pondasi sains dan ilmu pengetahuan. Dengan adanya keterlibatan sainsa dan ilmu pengetahuan yang dilakukan sebelum peraturan tersebut terbit adalah bentuk upaya bahwa semua rencana, kebijakan dan program tepat guna dan sohih sasaran. Karena, ilmu pengetahuanlah yang dapat membedakan dan memiliki berbagai proses yang objektif dalam melihat berbagai persoalan. Artinya, proses atau prosedur dalam pembentukan perudang-undangan menjadi sangat penting.

Persoalan yang tidak alah penting untuk diteliti adalah implikasi dari permohonan uji formil terhadap undang-undang yang dikabulkan. Apakah implikasi yang ditimbulkan sama dengan dengan pengujian pada aspek formil. Sebab, mengingat dari beberapa pendapat dia atas menyebutkan bahwa aspek formil sangatlah penting dan urgen. Apalagi, jika melihat beberapa pendapat yang mengatakan bahwa tertib prosedural tidak hanya dimaknai sebagai prosedur biasa, melainkan juga menjadi gambaran kualitas pembentukan dari undang-undang itu sendiri ${ }^{33}$.

Jika melihat Pasal 51A ayat (3) huruf c menyatakan : "Undang-undang tersebut tidak mempunyai kekuatan hukum mengikat" ${ }^{34}$. Dalam penjelasan undang-undang tersebut juga disebut cukup jelas. Itu artinya, norma di atas tidak memerlukan penafsiran tambahan. Maknanya adalah, jika permohonan uji formil terhadap undangundang dikabulkan oleh hakim Mahkamah Konstitusi berimplikasi batalnya sebuah undang-undang. Produk lembaga legislatif tidak lagi mempunyai daya ikat kepada subyek hukum siapapun. Dengan begitu, jika menggunakan penafsiran original intens, maka jelas undang-undang yang alpa tertib prosedural akan berimplikasi terhadap batalnya atau hilangnya daya ikat.

Dus, semua putusan MK bersifat final dan mengikat, lebih-lebih kepada pembuat undang-undang. Mekanisme yang demikian ini, adalah hal ikhwal yang mungkin tumbuh sebab putusan MK atas suatu undang-undang yang mula-mula berlaku menjadi tidak lagi memiliki kekuatan hukum mengikat ${ }^{35}$. Tidak lagi ada upaya hukum apapun yang bisa dilakukan setelah ada putusan hakim MK selain

\footnotetext{
${ }^{33}$ A Daniel Oliver Lalana, "Legislative Deliberation and Judicial Review: Between Respect and Disrespect for Elected Lawmakers" (2019) 5 Springer Publishing.

34 note 19.

${ }^{35}$ Asshiddiqie, supra note 1.
}

144 HUKMY | Jurnal Hukum 
menganatkan kepada lembaga yang berwenang membuat undang-undang untuk merubah peraturan tersebut atau melakukan perbaikan prosedur agar seseuai dengan peraturan perudang-undangan.

Ketentuan bahwa putusan Mahkamah Konstitusi memperoleh kekuatan tetap sejak selesai dibacakan dalam sidang hukum pleno terbuka untuk umum, berlaku perspektif ke depan (foreward looking), tidak retrospektif (backward looking) ${ }^{36}$. Dengan begitu, putusan hakim MK yang memiliki sifat final dan mengikat (final and binding), berimplikasi agar ada perubahan yang sesuai dengan putusan MK dan peraturan perundang-undangan. Dengan negitu, tertib prosedural juga berlaku semua prinsip bahwa pembetukan peraturan perundang-undangan harus disesuaikan dengan peraturan perundang-undangan.

Memang, jika melihat dari norma dalam UUD NRI, tidak pernah ditemukan tertib formil secara eksplisit. Konstitusi tidak secara tegas menyebut konten, syarat dan lainnya pada aspek prosedur dalam membentuk peraturan perundang-undangan. Rujukan utama tertib prosedura tersebut hanya bersifat undang-undang. Secara hirarki, undang-undang dengan undang-undang memiliki hirarki yang sama. Akan tetapi semua undang-undang haruslah berpedoman pada tata cara yang diatur dalam undang-undang yang mengatur pan-pembentukan peraturan perundang-undangan.

Melihat Pasal 51A ayat (3) huruf berbunyi : "menyatakan bahwa pembentukan undang-undang dimaksud tidak memenuhi ketentuan pembentukan undang-undang berdasarkan Undang-Undang Dasar Negara Republik Indonesia Tahun 1945"37. Dasar yang digunakan dalam pengujian prosedural memang menyebutkan undang-undang tentang pembentukan jenis dan bentuk undang-undang. Akan tetapi, undang-undang tentang pembentukan undang-undang tersebut adalah amanah dan pengejwantahan dari norma-norma yang ada dalam UUD NRI.

Oleh sebab itu, legitimasinya adalah legitimasi dari UUD NRI karena semangat dan ruhnya adalah konstitusi itu sendiri. Dengan begitu, aspek prosedural tyidak lagi dipandang sebagai aspek yang syarat dan berbagai tertibnya hanya berdasar pad undang-undang saja. Batasan tertib prosedural tersebut memang tidak secara tegas disebutkan dalam konstitusi sebab UUD NRI alaha aturan pokok-dasar yang kontennya

\footnotetext{
36 Ibid.

37 note 19.
} 
tentu sangatlah umum dan asbtrak. Secara tehnis, perlu diatur dengan peraturan pelaksana dari UUD NRI, yakni dengan undang-undang.

\section{KESIMPULAN}

Dari kajina di atas dapat disimpulkan bahwa pengaturan tentang pengujian sebuah undang-undang pada aspek formil diatur dalam bentuk undang-undang. Undang-undang yang dimaksud adalah undang terkait dengan pembentukan peraturan perundang-undangan. Jenis undang-undang ini menjadi pedoman dalam mebnetuk undang-undang. Hakim MK dapat menggunakan undang-undang ini dalam menjalakan tugas pengujian formil. Sebab, validitas sebuah undang-undang tidak hanya bergangtung pada UUD NRI sebagai aturan yang secara hirarki berada di atasnya. MK juga dapat dan diwajibkan menggunakan undang-undang tentang pembentukan undang-undang karena amanah dan terdapat ruh UUD NRI di dalamnya.

Tetapi, dalam praktik, MK tidak pernah mengabulkan permohonan pengujian undang-undang pas aspek formil. Ratio legis yang dibangun oleh MK dalam menggelar perkara pengujian formil masih terlalu klise. Sehingga, tidak pernah ada undangundang yang permohonan dikabulkan oleh MK. Padahal, aspek formil juga memiliki daya dukung terkait kualitas sebuah undang-undang. Karena, pada aspek formil terdapat beberapa intrumen inti, yang apabila dihilangkan dalam proses pembentukan undang-undang, maka sebuah undang-undang tidaklah punya legitimasi kokoh. Salah satunya adalah aspek keterbilatan publik yang dalam optik negara demokrasi, menjadi unsur vital.

Implikasi dari pengujian formil berberda dengan pengujian pada aspek materil. Pengujian materil berimplikasi batalnya sebagian ayat, pasal atau bahkan keseluruhan norma dalam undang-undang tersebut. Kebatalan pada pengujian metril tergantung pada muatan materi apa yang dimintakan untuk dibatalkan dan pada konten apa juga hakim MK memberi putusan. Artinya aspek materil bergantung pada sejumlah bagian dari materi apa saja yang dianggap bertentangan dengan konstitusi.

Pada aspek formil, implikasi dari model pengujian ini adalah batalnya keseluruhan undang-undang yang sudah ditetapkan. Kekuatan hukum mengikatnya sebuah undang-undang yang sudah diundangkan dalam lemabaran negara menjadi hilang apabila teradpat putusan MK yang mengabulkan permohonan pengujian. Keadaanya ini dipertegas pada Pasal 51A UU MK. Walaupun, pada praktiknya, MK 
tidak pernah mengabulkan perkara pengujian undangundang pada aspek formil di MK.

\section{DAFTAR PUSTAKA}

Asshiddiqie, Jimly, Hukum Acara Pengujian Undang-Undang (Jakarta: Konstitusi Press, 2006).

-_- Setengah Abad Jimly Asshiddiqie, Konstitusi dan Semangat Kebangsaan (Jakarta: PT Sumber Agung, 2006).

Boli Sabon, Max, Fungsi Ganda Konstitusi (Bandung: PT Grafiti, 1991).

Joeniarto, Undang-Undang Dasar 1945 Sebagai Hukum Negara yang Tertinggi (Jakarta: PT Bina Aksara, 1982).

Siahan, Murarar, Hukum Acara Mahkamah Konstitusi Republik Indonesia (Jakarta: Sinar Grafika, 2012).

Soebechi, Imam, Hak Uji Materiil, cet. 1 ed (Jakarta: Sinar Grafika, 2016).

Soemantri, Sri, Hak Menguji Material di Indonesia (Bandung: Penerbit Alumni, 1986).

Soimin \& Mashuriyanto, Mahkamah Konstitusi Dalam Sistem Ketatanegaraan Indonesia (Yogyakarta: UII Press, 2013).

Undang-Undang Republik Indonesia Nomor 8 Tahun 2011 Perubahan Atas UndangUndang Nomor 24 Tahun 2003 Tentang Mahkmah Konstitusi (Lembaran Negara Republik Indonesia Tahun 2011 Nomor 70).

Anonimous, "Eksistensi Lembaga Negara, Berdasarkan UU Negara RI Tahun 1945" (2007) Vol 4 Jurnal Legislasi.

F Zurn, Christopher, "Deliberative Democracy and the Institutions of Judicial Review" (2007) Cambridge University Press New York.

Isra, Saldi, "Peran Mahkamah Konstitusi dalam Penguatan Hak Asasi Manusia Di Indonesia" (2014) Vol. 11 Jurnal Konstitusi.

Mahrus Ali, Mohammad, "Konstitusionalitas dan Legalitas Norma dalam Pengujian Undang-Undang Terhadap Undang-Undang Dasar 1945” (2015) 12 Jurnal Konstitusi.

Oliver Lalana, A Daniel, "Legislative Deliberation and Judicial Review: Between Respect and Disrespect for Elected Lawmakers” (2019) 5 Springer Publishing. 
Palguana, I Dewa G, “Constitutional Question : Latar Belakang dan Praktik Di Negara Lain Serta Kemungkinan Penerapannya Di Indonesia” (2010) Vol. I Ius Quia Iustum.

Rishan, Idul, "Konsep Pengujian Formil Undang- Undang di Mahkamah Konstitusi” (2021) 18 Jurnal Konstitusi.

Media, Kompas Cyber, “Menakar Kekuatan Politik Partai Koalisi Pemerintah di Tengah Menguatnya Wacana Amendemen UUD 1945... Halaman all”, (1 September 2021), online: KOMPAS.com <https://nasional.kompas.com/read/2021/09/01/19461631/menakarkekuatan-politik-partai-koalisi-pemerintah-di-tengah-menguatnya>.

Tim Penyusun, Hukum Acara MK (Sekretariat Jenderal dan Kepaniteraan, Mahkamah Konsititusi, Jakarta, 2010).

Undang-Undang Nomor 24 Tahun 2003 tentang Mahkamah Konstitusi (Lembaran Negara Republik Indonesia Tahun 2003 Nomor 98). 